\title{
Innovations
}

\section{Anatomy of Melancholy: An Arabic take on an English classic}

Medical Humanities in the Middle East Conference

\author{
November 17-18, 2018 \\ Doha, Qatar
}

\section{Authors}

\section{Georges Haddad $^{*}$}

\section{Abstract}

In 1621, Robert Burton published The Anatomy of Melancholy. The 900-page volume purported to present an exhaustive study of melancholy. The primary reason, or at least the pretext, Burton gives for composing his opus is 'by being busy to avoid melancholy'. He went on to work unceasingly on his opus magnum that would become a bestseller and grow to more than 2000 pages by the posthumous sixth edition. The work is divided into three sections. The first section is devoted to the "Kinds, Causes, Symptomes, Prognostickes," of the disease; the second section deals with "Several Cures of it." And the last section is devoted to two particular forms of melancholy: Amorous and Religious melancholies.
The etymology of the word "melancholy" is derived from the conflation of two Greek words: melas "black" and khole "bile". In the fifth century BCE Hippocrates wrote: "Fear or despondency persevering for a long time means melancholy". This notion of Black Bile as the cause of melancholy will be further refined by Rufus of Ephesus (late 1st century CE ) and later on by Galen (129 CE - c. 216 CE ). The Anatomy of Melancholy cites several Arab physicians either by name or as a group as is evident by the following citation: "Avicenna therefore holds both corrupt, to whom most Arabians subscribe."

I reviewed the input of medieval Arab physicians and placed them in context, stressing the fact that they did not act solely as a bridge between Galen and European renaissance physicians but refined the Hippocratic and Galenic notions through successive iterations, expanded the classification of the disease and advanced its treatment. I
'American University of Beirut, Beirut, Lebanon

*Email: gfshaddad@gmail.com

\section{Cite this article as:}

Haddad G. Anatomy of Melancholy: An Arabic take on an English classic. In: Weber AS, Verjee MA, editors. Proceedings of the 1st International Conference on Medical Humanities in the Middle East [Internet]; 2018 Nov 17-18: Doha, Qatar: Innovations in Global Health Professions Education; 2019 March. p. 39-40. (Innovations in Global Health Professions Education; vol. 2019, spec. no.: 1). https://dx.doi.org/10.20421/ighpe2019.01.13

This is an open access article distributed under the terms of the Creative Commons Attribution license CC BY 4.0, which permits unrestricted use, distribution and reproduction in any medium, provided the original work is properly cited. 
review the input of several Arab luminaries on the subject: al-Rhazi, ibn 'Imrān, Al-Majūsī and Ibn Sînâ and quote in detail the seminal work of Ishāq ibn 'Imrān (d. 932 CE) Treatise on melancholy which was translated by Constantine the African into Latin (1065). Constantine presented De Melancholia as his own original work; it served as the primary reference for the treatment of mood disorders in Europe for over five centuries. The present study of Melancholia will quote from medieval Arabic texts and provide vis-à-vis translations.

The actual notion of Melancholy would change as it went through the Arab prism. Whereas melancholy for the Greeks and Latins is most akin to our present-day notion of Depression, some of the Arab authors (ibn 'Imrān and Ibn Sînâ) will expand the definition to include a variety of mental disorders such as Leonine Madness, akin to our present-day Mania. Whereas Galen ascribed melancholy solely to Black Bile, the completed scheme of Ibn Sînâ ascribes four different causes for melancholy, each based on a different humor: Yellow Bile, Black Bile, Phlegm and Blood.

Burton enlivened his text with a plethora of literary quotations in Latin and English and as a nod to Burton's extensive quotations, I reference my work with excerpts from the Arabic poetic corpus. This presentation sits squarely at the intersection of the arts of Medicine and Humanities. Like its illustrious predecessor, The Anatomy of Melancholy, it aims to be informative and entertaining albeit on a much more accessible scale.

\section{Conflicts of interest: None.}

Funding sources: None.

\section{About the author}

Dr. Georges Haddad, MD, FRCS(C), is Clinical Associate Professor of Neurosurgery at the American University of Beirut, Lebanon. He is Fellow of the Royal College of Surgeons (Canada) and is American board certified in neurosurgery. He is the author of numerous book chapters and articles in neurosurgery and was president of the Lebanese Society of Neurosurgery and Vice-President of the World Association of Lebanese Neurosurgeons. He is also an avid reader and has a keen interest in history and philosophy. 